\title{
Biliary tract schwannoma:A rare case of obstructive jaundice in a middle aged gentleman.
}

\author{
Vishakha Kalikar, SachinWani, Roy Patankar, S.K. Mathur \\ Department of General Surgery, Zen Hospital, India
}

\begin{abstract}
Schwannomas are derived from Schwann cells, the most common sites being upper extremiteis, trunk, retroperitoneum, head and neck, mediastinum. However they can arise from the gastrointestinal tract too, including the biliary system. We present a case of a 40 year old gentleman, who presented with obstructive jaundice whose computed tomography of the abdomen was suggestive of mass lesion at the porta causing intra hepatic biliary radicle dilatation. And MRCP s/o similar findings with an endosonography s/o hydatid cyst. He underwent local resection with biliary enteric reconstruction and the histopathological examination confirmed a biliary duct schwannoma. On follow at 6 months, the patient is a symptomatic and shows no signs of recurrence. We have also reviewed the literature of biliary tract schwannomas.
\end{abstract}

Keywords: Biliary Tract, Hilarcholangiocracinoma, Schwannoma

\section{Introduction}

Schwannomas are rare tumors of the digestive tract although other non-epithelial tumors such as adenomas, lymphomas can mimic a cholangicarcinoma. $(1,2)$.The aim of this case report was to put forth a case of a common bile duct schwannoma that caused obstructive jaundice in a middle aged male patient. It was diagnosed during surgery, hence allowing a local resection with reconstruction to be carried forward.

\section{Case}

We had a 40 year old gentleman, clinically diagnosed with obstructive jaundice, history of hepatitis twice in the past 1 year with $12 \mathrm{kgs}$ weight loss in the past 3 months. No history of any addictions. On clinical examination there was no organomegaly. Laboratory studies: Total bilirubin: 12 with direct being 8 . SGOT /SGPT: 153/ 168 respectively, alkaline phosphatase being 600. Tumor markers were within normal limits. Computed tomography of the abdomen with oral/iv contrast: $32 \times 29 \mathrm{~mm}$ mass at the porta causing intra hepatic biliary radicle dilatation. The adjacent vascular structures and fat planes werepreserved.Magnetic resonance cholangiography s/o thin walled cystic mass at the porta. Endosonographys.o ?hydatid cyst at the porta. We opted for surgical resection of the mass and began with a laparoscopic approach.intra operatively: a large solid cystic mass arising from the common bile duct with splaying of the CBD anterior to the mass. Decision wastaken to convert to open. During dissection we found a well-encapsulated, solid cystic mass with regular margins with no signs of infiltration into the surrounding structures. A cholecystectomy was performed with en bloc resection of the mass along with CBD and a Roux en Y hepaticojejunostomy.

Post operative course of the patient was uneventful. Patient was discharged on day 7 in a healthy condition. Histopathological confirmed it to be a primary biliary schwannoma with free margins and node negative with immunohistochemistry being positive for S100. It was negative for CD 117 kit and CD 34.At a follow up after 6 month the patient is asymptomatic without any signs of recurrence.

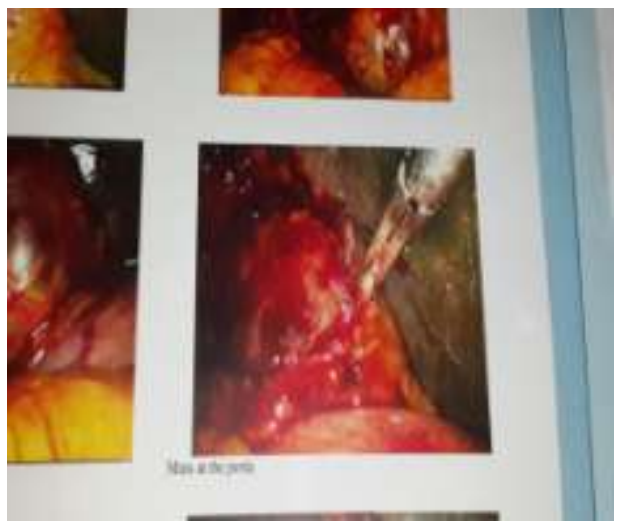

Fig 1:Intraoperative findings: solid cystic mass lesion at the porta 


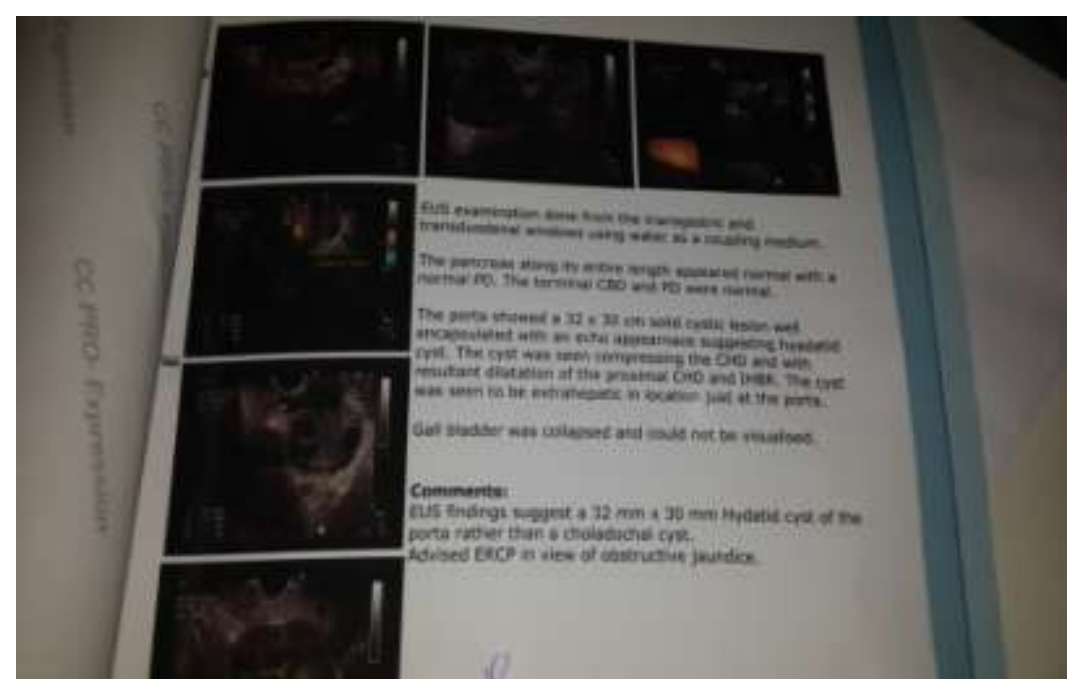

Fig2:EUS report suggestive of hydatid cyst

We found 15 cases in literature of the same as depicted in the table below.

Cases studies of biliary schwannoma in the literature

\begin{tabular}{|c|c|c|c|c|c|c|}
\hline Oburvatinav referunces & $\operatorname{Agn}(y r)$ & $5 e s$ & Signals gutuptoms & Initial diagnenis & Lacation of tumar & \begin{tabular}{|l} 
Propentive tinue \\
acquinition
\end{tabular} \\
\hline Odea taI[1] & 40 & $F$ & $\begin{array}{l}\text { Abdosinat pain * obstructive } \\
\text { jandice }\end{array}$ & Covidochalithusts & Cenmsen bile buet & $\mathrm{No}$ \\
\hline Bareuet et a[1] & 15 & $\mathrm{~F}$ & 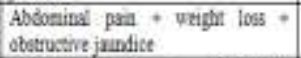 & & 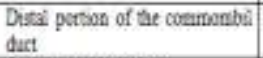 & No \\
\hline 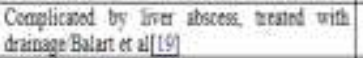 & 56 & $F$ & $\begin{array}{l}\text { Absominal pain " obscuxtive } \\
\text { janndice }\end{array}$ & 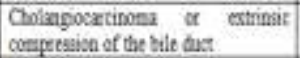 & Comentm beperic dust & No \\
\hline Jabobs et al[3] & $3 ?$ & $\mathrm{M}$ & $\begin{array}{l}\text { Abdoanina pain + obstuctive } \\
\text { amodice }\end{array}$ & Intra-ductsil berign tumor & Comenom lepatic dust & Yes \\
\hline Hogio ex allu & 48 & $F$ & Costructive jaudice & Bengr bos-quitbdial timar & Cormong bile dust & 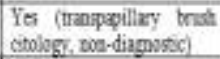 \\
\hline Orai ex a[d] & 59 & $F$ & Abojoninal pas & & $\begin{array}{l}\text { Remusit bile dont (panstatic } \\
\text { parbon) }\end{array}$ & No \\
\hline Parket a.[2य] & 53 & F & Assmitcuatic & & Portabeguis & $\mathrm{Na}$ \\
\hline Vyes at a[2] & 29 & $F$ & $\begin{array}{l}\text { AbSonind pat + obsutive } \\
\text { jamdiat }\end{array}$ & & Cenmentile buet & Yes (pas disgabsts) \\
\hline Kamini et a & 39 & F & Jandise + weight loses & Katsin nuave & $\begin{array}{l}\text { ?tosemi portion of the corrmatm } \\
\text { hestit bat }\end{array}$ & $\mathrm{No}$ \\
\hline 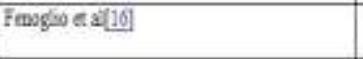 & 41 & $\mathrm{~F}$ & Destructive juadice + weight hos & & $\begin{array}{l}\text { Modile segment of the conmsm } \\
\text { Bie dad }\end{array}$ & $\mathrm{Ne}$ \\
\hline Juge $x \mathrm{a}[(])$ & 64 & F & Assmg̨toenutic & & $\begin{array}{l}\text { Provimal porion of the corrensen } \\
\text { bive dext }\end{array}$ & No \\
\hline Madtusudan ex al[i] & 46 & $\mathrm{M}$ & Oostructive iandict & Versable polypoidcbalmgiocarchoms & Intrabequatic bele dart & Yes \\
\hline Kulkani et a(d) & 38 & $M$ & 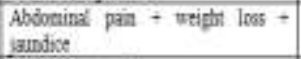 & & Comenom bile dust poctabepots & No \\
\hline $\begin{array}{l}\text { Patient has von Reckingtasens disease De } \\
\text { Sena ex d [29 }\end{array}$ & 58 & $F$ & Ohonutive jamdice & Bthay xtmarnoma & Extrahogatic ble duet & No \\
\hline 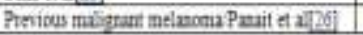 & 54 & $\mathrm{~F}$ & 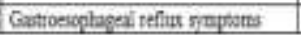 & Besurtent metatatic melanoma & Poctahequas & Yes (pon-4japnostis) \\
\hline
\end{tabular}

F: Female; M: Male.

\section{Discussion}

Schwannomas are tumors derived from Schwann cells i.e. from the inner portion of the nerve sheath. (3).The most common locations are upper extremities, head and neck, trunk, retroperitoneum, mediastinum and pelvis. (4). Schwannomas of the gastrointestinal tract are uncommon, the most common sites being the stomach and colon. (5), though they can develop along the biliary tract because of the abundance of the sympathetic and parasympathetic supply along the wall of the gall bladder and the CBD (6) These have a female preponderance and most commonly present with obstructive jaundice.

We have no conclusive diagnostic imaging studies for the same as schwannomas simulate findings similar to other tumors especially cholangiocarcinoma. Histopathologically on gross examination they are usually large, solitary cystic and the nerve of origin doesn't penetrate the tumor. In the mediastinum it is also known a dumbbell tumor.

Microscopically there are AntoniA which compact and highly cellular, containing spindle cells and Antoni B areas, whichconsist of loose myxoid tissue containing spindle cells, with degenerative changes. (7) There are 4 types of schwannomas: cellular, glandular, epitheloid and ancient. The cellular type contains Antoni 
a type cells, epitheloid and granular contains cells according to their name and ancient type: bizarre hyper chromatic nuclei with cyst formation, calcification and hyalinization.

Immunohistochemistry is essential to distinguish schwanomas from other tumors like neurofibromas, liposarcomas, stromal tumors. Schwannomas are strongly positive for S100 and viementin but negative for CD 117 kit, which are found in smooth muscle cell tumors. (8) CD 34, which is expressed in the stromal cell tumors, is usually negative in schwannomas. Our patient tested positive for S 100 but negative for CD 34.

\section{Conclusion}

The diagnosis of schwannomas finally required histopathological examination. (9). Resection is the treatment of choice for such cases. (10). Schwannomas have an excellent prognosis after surgical resection. To date there has been no data that they can be potentially malignant. (6).biliary tract schwannoma is extremely rare and is mostly seen in the extra hepatic bile duct. A radiological diagnosis is difficult

\section{References}

[1]. Eslick GD. Epidemiology of gallbladder cancer. GastroenterolClin North Am. 2010;39:307-330

[2]. Malhi H, Gores GJ. Cholangiocarcinoma: modern advances in understanding a deadly old disease. J Hepatol. 2006;45:856-867

[3]. Hajdu SI. Peripheral nerve sheath tumors. Histogenesis, classification, and prognosis. Cancer. 1993;72:3549-3552.

[4]. Kulkarni N, Andrews SJ, Rao V, Rajagopal KV. Case report: Benign porta hepatic schwannoma. Indian J Radiol Imaging. 2009;19:213-215.

[5]. iettinen M, Shekitka KM, Sobin LH. Schwannomas in the colon and rectum: a clinicopathologic and immunohistochemical study of 20 cases. Am J SurgPathol. 2001;25:846-855.

[6]. ung JH, Joo KR, Chae MJ, Jang JY, Lee SG, Dong SH, Kim HJ, Kim BH, Chang YW, Lee JI, et al. Extrahepatic biliary schwannomas: a case report. J Korean Med Sci. 2007;22:549-552.

[7]. Honjo Y, Kobayashi Y, Nakamura T, Takehira Y, Kitagawa M, Ikematsu Y, Ozawa T, Nakamura H. Extrahepatic biliary schwannoma. Dig Dis Sci. 2003;48:2221-2226.

[8]. Hou YY, Tan YS, Xu JF, Wang XN, Lu SH, Ji Y, Wang J, Zhu XZ. Schwannoma of the gastrointestinal tract: a clinicopathological, immunohistochemical and ultrastructural study of 33 cases. Histopathology. 2006;48:536-545.

[9]. de Diego Rodríguez E, Roca Edreira A, MartínGarcía B, HernándezRodríguez R, Portillo Martín JA, GutiérrezBaños JL, CorreasGómez MA, del Valle Schaan JI, Villanueva Peña A, Rado Velázquez MA, et al. [Retroperitoneal benign schwannoma. Report of a new case] ActasUrol Esp. 2000;24:685-688.

[10]. Fenoglio L, Severini S, Cena P, Migliore E, Bracco C, Pomero F, Panzone S, Cavallero GB, Silvestri A, Brizio R, et al. Common bile duct schwannoma: a case report and review of literature. World J Gastroenterol. 2007;13:1275-1278. 